\title{
Genomewide association study for onset age in Parkinson disease
} Jeanne C Latourelle ${ }^{\dagger 1}$, Nathan Pankratz ${ }^{\dagger 2}$, Alexandra Dumitriu1, Jemma B Wilk¹, Stefano Goldwurm³ ${ }^{3}$, Gianni Pezzoli ${ }^{3}$, Claudio B Mariani ${ }^{3}$, Anita L DeStefano ${ }^{1,4}$, Cheryl Halter ${ }^{2}$, James F Gusella ${ }^{5}$, William C Nichols ${ }^{6}$, Richard H Myers*1, Tatiana Foroud*2 and the PSG -PROGENI and GenePD Investigators, Coordinators and Molecular Genetic Laboratories

\author{
Address: ${ }^{1}$ Boston University School of Medicine, Boston, MA, USA, ${ }^{2}$ Indiana University School of Medicine, Indianapolis, IN, USA, ${ }^{3}$ Parkinson \\ Institute, Istituti Clinici di Perfezionamento, Milano, Italy, ${ }^{4}$ Boston University School of Public Health, Boston, MA, USA, ${ }^{5}$ Massachusetts General \\ Hospital and Harvard Medical School, Boston, MA, USA and ${ }^{6}$ Cincinnati Children's Hospital Medical Center and University of Cincinnati College \\ of Medicine, Cincinnati, Ohio, USA \\ Email: Jeanne C Latourelle - jlatoure@bu.edu; Nathan Pankratz - npankrat@iupui.edu; Alexandra Dumitriu - adumitri@bu.edu; \\ Jemma B Wilk - jwilk@bu.edu; Stefano Goldwurm - goldwurm@parkinson.it; Gianni Pezzoli - Pezzoli@parkinson.it; \\ Claudio B Mariani - mariani@parkinson.it; Anita L DeStefano - adestef@bu.edu; Cheryl Halter - chalter@iupui.edu; \\ James F Gusella - gusella@helix.mgh.harvard.edu; William C Nichols - Bill.Nichols@cchmc.org; Richard H Myers* - rmyers@bu.edu; \\ Tatiana Foroud* - tforoud@iupui.edu; the PSG -PROGENI and GenePD Investigators, Coordinators and Molecular Genetic \\ Laboratories - rmyers@bu.edu \\ * Corresponding authors †Equal contributors
}

Published: 22 September 2009

BMC Medical Genetics 2009, 10:98 doi:10.1 186/1471-2350-10-98
Received: 6 April 2009

Accepted: 22 September 2009

This article is available from: http://www.biomedcentral.com//47/-2350/I0/98

(c) 2009 Latourelle et al; licensee BioMed Central Ltd.

This is an Open Access article distributed under the terms of the Creative Commons Attribution License (http://creativecommons.org/licenses/by/2.0), which permits unrestricted use, distribution, and reproduction in any medium, provided the original work is properly cited.

\begin{abstract}
Background: Age at onset in Parkinson disease (PD) is a highly heritable quantitative trait for which a significant genetic influence is supported by multiple segregation analyses. Because genes associated with onset age may represent invaluable therapeutic targets to delay the disease, we sought to identify such genetic modifiers using a genomewide association study in familial PD. There have been previous genomewide association studies (GWAS) to identify genes influencing PD susceptibility, but this is the first to identify genes contributing to the variation in onset age.
\end{abstract}

Methods: Initial analyses were performed using genotypes generated with the Illumina HumanCNV370Duo array in a sample of 857 unrelated, familial PD cases. Subsequently, a meta-analysis of imputed SNPs was performed combining the familial PD data with that from a previous GWAS of 440 idiopathic PD cases. The SNPs from the meta-analysis with the lowest $\mathrm{p}$-values and consistency in the direction of effect for onset age were then genotyped in a replication sample of 747 idiopathic PD cases from the Parkinson Institute Biobank of Milan, Italy.

Results: Meta-analysis across the three studies detected consistent association $\left(p<1 \times 10^{-5}\right)$ with five SNPs, none of which reached genomewide significance. On chromosome II, the SNP with the lowest $p$-value $\left(r\right.$ I076797I; $\left.p=5.4 \times 10^{-7}\right)$ lies between the genes QSERI and PRRG4. Near the PARK3 linkage region on chromosome 2pI3, association was observed with a SNP ( $r$ 757785 I; $\left.p=8.7 \times 10^{-6}\right)$ which lies in an intron of the AAKI gene. This gene is closely related to GAK, identified as a possible PD susceptibility gene in the GWAS of the familial PD cases.

Conclusion: Taken together, these results suggest an influence of genes involved in endocytosis and lysosomal sorting in PD pathogenesis. 


\section{Background}

Parkinson disease (PD), the second most common neurodegenerative disorder, is characterized by debilitating symptoms of tremor, rigidity, and bradykinesia, usually occurring late in life. PD incidence increases with age from $1.7 / 10,000$ person-years between ages 50 to 59 to $9.3 /$ 10,000 person-years between ages 70 to 79 and has a prevalence of approximately $1.8 \%$ among people over the age of 65 [1]. While the average age of onset of PD is approximately 60 years, there is wide variation, with some individuals having onset before age 20 and others not until after age $90[2,3]$.

Five monogenic forms of PD have been identified and characterized by mode of transmission, onset age and protein affected by mutation. These include $\alpha$-synuclein (SNCA or PARK1) [4], parkin (PARK2) [5], PTEN-induced putative kinase 1 (PINK1 or PARK6) [6], DJ-1 (PARK7) [7], and leucine-rich repeat kinase 2 (LRRK2 or PARK8) [8]. Onset for PARK1 is younger than that seen for idiopathic PD [4]. PARK2 (parkin) is a recessive form with young onset, commonly before age 40 . Heterozygous mutations in parkin are also associated with earlier onset of PD, typically in the early to mid sixth decade $[9,10]$. By contrast, PD associated with $L R R K 2$ mutations presents an onset distribution very similar to that seen in idiopathic $\mathrm{PD}$, as well as clear age-dependent penetrance [11-13].

Onset of PD has been shown to be correlated between siblings with PD [14] suggesting that genetic modifiers influence onset age. Segregation analyses in three independent studies showed evidence of a genetic effect influencing age of onset of PD [15-17]. Notably, all three of these segregation analyses showed stronger evidence for the presence of "major genes" influencing onset age or penetrance, than for genes influencing susceptibility. Furthermore, age is one of the strongest risk factors for PD, suggesting that age related penetrance is strongly associated with disease expression. By identifying genes related to onset age, it may be possible to identify pathogenic mechanisms and therapeutic targets capable of delaying onset of disease symptoms. Effectively postponing disease onset will reduce disease prevalence and ease the burden of $\mathrm{PD}$ in our aging population.

All prior PD genome wide association studies (GWAS) have focused exclusively on the detection of susceptibility genes and none has investigated association to genes influencing onset age [18-20]. In this study, we describe the first GWAS of onset age. This GWAS included 857 PD cases with a positive family history of PD. In addition, we performed a second GWAS with onset age as the phenotype using publicly available data from 440 randomly ascertained PD cases [19]. We conducted a meta-analysis of the two studies comprising approximately 2 million
SNPs imputed using HapMap data. Finally, a replication study of the top findings from the meta-analysis was performed in an independent sample of 747 randomly ascertained PD cases from Milan, Italy.

\section{Methods \\ PD Cases}

One PD case $(\mathrm{n}=935)$ from each family recruited from two ongoing studies of familial PD, the GenePD study and the PROGENI study, was selected for the GWAS. Both studies recruited families consisting of at least two members meeting diagnostic criteria for PD. PD cases underwent a uniform neurological evaluation that employed PD diagnostic criteria based on a modified version of the United Kingdom PD Society Brain Bank Criteria [21]. Detailed descriptions of the inclusion and exclusion criteria are described elsewhere for the PROGENI [22] and GenePD [14] studies. The analyzed sample was exclusively white, non-Hispanic.

No subject known to have a disease-producing mutation was included in this analysis. All cases were known to be negative for the LRRK2 G2019S mutation, and many, but not all, were also screened for PARK1(SNCA)(N screened = 702), PARK2 (parkin) $(\mathrm{N}=593)$, PARK7 $(D J 1)(\mathrm{N}=328)$, and NR4A2 ( $\mathrm{N}=550)[9,10,12,23-27]$. PD onset age was determined by interview and reflected the age of first symptom of PD, which commonly preceded age of physician diagnosis. The reliability of ascertaining age of onset though interview compared to medical records has been estimated as 0.94 [28].

In addition, control samples $(\mathrm{n}=895)$ obtained from the NINDS Human Genetics Resource Center DNA and Cell Line Repository (Camden, NJ) were intermixed on the same plates as the cases when genotyped. All selected control samples were reported to be white, non-Hispanic. While not used in the analysis of onset age of PD, these samples were used for SNP and sample quality assessment and genotype imputation as described below.

Appropriate written informed consent was obtained for all samples included in this study.

\section{Microarray Genotyping and Quality Assessment}

Genotyping was performed by the Center for Inherited Disease Research (CIDR) using the Illumina HumanCNV370 version1_C BeadChips (Illumina, San Diego, CA, USA) and the Illumina Infinium II assay protocol [29]. As previously described [20], 78 cases and 28 controls were removed due to a low genotype call rate ( $<98 \%$ of SNPs), cryptic relatives in the sample, or population stratification. The final sample included $857 \mathrm{PD}$ cases (all derived from whole blood) and 867 control DNA samples (all derived from lymphoblastoid cell 
lines). Genotype calls and quality scores were determined from allele cluster definitions for each SNP as determined by the Illumina BeadStudio Genotyping Module version 3.1 .14 and the combined intensity data from $96 \%$ of study samples as previously described [20]. Genotype calls with a quality score (Gencall value) of 0.25 or higher were considered acceptable. Blind duplicate reproducibility was $99.98 \%$. Although we performed additional SNP filtering described below, the CIDR released dataset contained 344,301 SNPs and is available on dbGaP (http:// www.ncbi.nlm.nih.gov/sites/entrez?db=gap; Accession number: phs000126.v1.p1).

SNPs were removed if: 1) the call rate of the SNPs was lower than $98 \%(n=7,764), 2)$ the minor allele frequency was less than 0.01 in the combined case and control dataset $(n=7,667), 3)$ there were differential rates of missing genotypes in the cases and controls $(\mathrm{n}=75)$ or males and females ( $\mathrm{n}=271)$, or 4$)$ significant deviation from Hardy Weinberg equilibrium was observed in the control sample $(\mathrm{n}=906)$. Many markers failed multiple tests. The final dataset consisted of 328,189 SNPs that passed all quality control measures (94.6\% of all attempted SNPs).

\section{Mayo-Perlegen LEAPS sample}

Publicly available SNP genotype data for 443 PD cases was accessed from dbGaP for the GWAS "Mayo-Perlegen LEAPS (Linked Efforts to Accelerate Parkinson's Solutions) Collaboration" (http://www.ncbi.nlm.nih.gov/ sites/entrez? $\mathrm{db}=$ gap; $\quad$ Accession number: phs000048.v1.p1; [19]. This data set included genotyping for the 198,345 SNPs meeting the quality control standards described by Maraganore et al. [19]. We examined these data for population stratification and for cryptic relatedness. While no population outliers were observed, three individuals were removed due to apparent seconddegree relationships identified during our review of the data, leaving a sample of 440 PD cases included in these analyses. While data are also publicly available for 267 PD cases from the Fung et al. GWAS [18], that study only included cases whose age of PD onset was 55 years or greater resulting in an age distribution that was significantly different from the other two samples ( $p<0.0001)$. Therefore, we did not include the cases from that study in our meta-analysis due to limited variability in the onset distribution.

\section{Population stratification}

Both the GenePD-PROGENI and Mayo-Perlegen LEAPS sample sets were screened for population outliers during initial QC. In addition, after the final study sample sets were determined, principle components were recalculated independently for each study using only the samples included in the final analyses. Association to onset age was then tested for the first six principle components for each study. No association $(\mathrm{p}<0.05)$ between the first six principle components and onset age was seen in either study sample.

\section{Imputation}

Imputation was performed to increase the power of the meta-analysis and to facilitate the joint analysis of results generated from Mayo-Perlegen LEAPS and our GWAS, which were genotyped on different platforms. The program MACH 1.0 (compiled using Intel's optimized compiler) was used to impute genotypes for 2,543,887 autosomal SNPs characterized in the HapMap project [3032].

The GenePD-PROGENI sample and the Mayo-Perlegen LEAPS cohort were imputed separately using phased haplotype data downloaded from the HapMap project website [33].

In the GenePD-PROGENI sample, imputation was performed using both cases and controls. A subset of 200 cases and controls with high call rates was selected to perform the initial model parameter calculation. Next, imputation was performed on all participants using all autosomal SNPs where the strand was not ambiguous (i.e. not an A/T or G/C SNP) and that passed all other quality control measures described previously. In the Mayo-Perlegen LEAPS cohort, all PD cases were used to compute the initial model parameters. All unambiguous autosomal SNPs passing quality review, as described in the original Mayo-Perlegen LEAPS GWAS [19], were used for this imputation. In addition, because the genotyping platform used in the Mayo-Perlegen LEAPS study included a high percentage of ambiguous SNPs, those ambiguous SNPs which could be confidently matched to HapMap strands through the comparison of minor allele frequencies were also used for imputation. For each study, initial model parameters were calculated using 100 iterations. SNP quality was assessed using the Rsq metric, which estimates the squared correlation between imputed and actual genotypes with SNPs having an Rsq $<0.3$ excluded from further study $(\mathrm{N}=61,271)$.

At the time of this study, only autosomal imputation is supported by MACH; therefore, the program IMPUTE was used to impute SNPs on the X chromosome [34,35]http:/ /www.stats.ox.ac.uk/ marchini/software/gwas/

impute.html. Haplotype, legend, and recombination rate files based upon HapMap (rel\#21-NCBI build 35) were downloaded from IMPUTE's website for use in imputing 64,621 SNPs in the non-pseudoautosomal region of the X chromosome. Imputation was run in all participants in the GenePD-PROGENI study and separately in all PD cases in the Mayo-Perlegen LEAPS GWAS, using all Xchromosome SNPs that passed quality assessment as described above and were found in the legend file provided by IMPUTE. 


\section{Statistical Analyses}

In order to meta-analyze results from both studies, association to onset age was performed using exclusively imputed, not genotyped data, for 1,861,750 SNPs passing imputation QC and with minor allele frequencies greater than $10 \%$. Imputed SNPs with minor allele frequencies less than $10 \%$ in the GenePD-PROGENI sample $(\mathrm{N}=$ $620,866)$ were excluded from the association analyses to avoid false positives that can occur in the analysis of low minor allele frequency SNPs. To evaluate SNP association under an additive mode of inheritance, the predicted allele dosage for each genotype estimated by MACH for autosomes or by IMPUTE for the $\mathrm{X}$ chromosome was used. To model the recessive and dominant modes of inheritance, the genotype probabilities calculated by MACH were used. While a combination of additive and recessive models can have high power to detect dominant effects, this power decreases as the minor allele frequency of the SNP nears 0.5 [36]. Therefore, we studied additive, dominant and recessive models. The total probability of having either one copy or two copies of the minor allele was used for the dominant model and the probability of having two copies of the minor allele was used for the recessive model. Recessive and dominant models were not studied for the X chromosome. Linear regression analyses were performed using SAS v9.1.

\section{Meta-Analysis}

Since the genotypic data was generated on different arrays (Illumina and Perlegen) with few SNPs in common, we employed a conservative meta-analytic approach to combine results from the two studies. Meta-analysis of the results of the linear regression of the imputed data for the GenePD-PROGENI sample and the Mayo-Perlegen LEAPS cohort was performed using METAL http:// www.sph.umich.edu/csg/abecasis/metal/. As is common in GWAS meta-analyses, a fixed effects model with standard error weighting was used, as random-effects models may be too conservative in GWA studies with a small number of studies[37].

\section{Replication Study}

In order to validate the top findings from the GWAS metaanalysis, an additional sample of 896 PD cases with reported ages of PD onset was provided by the Parkinson Institute - Istituti Clinici di Perfezionamento, Milan, Italy from the "Human Genetic Bank of Patients Affected by PD and Parkinsonisms". These cases were recruited irrespective of family history or onset age, and similar to the GenePD-PROGENI, used the UK Parkinson's Disease Society Brain Bank criteria to confirm idiopathic PD [38] and defined onset as the age of first symptom of PD.

Twenty-four SNPs were selected based upon the following criteria (1) a p-value less than 0.00001 in the meta-analysis of the two GWAS, with (2) a consistent direction of effect in both studies. Nine SNPs meeting these criteria were identified from the additive inheritance model, thirteen from the dominant model and eleven from the recessive model. Four SNPs were identified in both the additive and dominant model, one SNP was identified in both the additive and recessive model and one SNP was identified by all three models. Three gene regions were identified under two different genetic models with different SNPs. For each multiply-nominated gene region, the SNP from the model with the smaller p-value was selected for replication. These SNPs were genotyped using TaqMan technology implemented on the ABI PRISM ${ }^{\circledast} 7900 \mathrm{HT}$ Sequence Detection system (Applied Biosystems: Foster City, CA) at Boston University School of Medicine. Individual samples (149) with genotyping call rates of less than $95 \%$ were excluded from further analysis.

Association of the 24 SNPs to onset age was evaluated in the 747 remaining Italian cases using linear regression performed with the software Plink v1.01 http:// pngu.mgh.harvard.edu/purcell/plink/[39] using the corresponding genetic model (additive, recessive or dominant) by which each SNP was originally identified. A final fixed effects meta-analysis of all three studies was performed using METAL.

To distinguish whether associations observed were to age in general, as opposed to age at onset of PD, linear regression to censoring age was performed in the 867 NINDS control samples genotyped with the GenePD-PROGENI cases.

\section{Results}

Demographic characteristics of the three samples studied are shown in Table 1. All three studies have a similar percentage of male participants. The GenePD-PROGENI and Mayo-Perlegen LEAPS samples have similar mean ages of PD onset, while the Italian sample has a somewhat younger average age at onset. The GenePD-PROGENI sample has the widest range of onset ages from 19 to 90 years while the Mayo-Perlegen LEAPS has no participants under 30 years of age and the Italian sample has no participants over 81 years of age. No significant differences in onset age are seen between men and women in any of the studies.

Supplementary Tables S1 (additive model), S2 (dominant model) and S3 (recessive model) (see Additional file 1) present the top SNPs from each region with a meta-analysis $\mathrm{p}<0.0001$ for imputed SNP data in the GenePD-PROGENI and Mayo-Perlegen LEAPS studies. Twenty-four SNPs with meta-analysis p-values of less than 0.00001 and with a consistent direction of effect for both GWAS were genotyped in the Italian replication sample of 747 PD cases (Table 2). SNPs genotyped in either the GenePDPROGENI or Mayo-Perlegen LEAPS GWAS platforms are 
Table I: Age and sex distribution of the GenePD- PROGENI, Mayo-Perlegen LEAPS, and Milan, Italian study samples.

\begin{tabular}{lccccc}
\hline & N & \% Male & Mean Onset & Std Dev Onset & Range Onset \\
\hline GenePD-PROGENI & 857 & 59.2 & 61.9 & 10.9 & $19-90$ \\
\hline Mayo-Perlegen LEAPS & 440 & 61.6 & 61.0 & 11.2 & $30-94$ \\
\hline Milan, Italian & 747 & 59.4 & 55.2 & 10.8 & $20-81$ \\
\hline
\end{tabular}

distinguished by notation from those SNPs imputed by both studies. The results of the association analysis in the Italian sample, as well as the combined meta-analysis of all three samples, are shown in Tables 3 (additive), 4 (dominant), and 5 (recessive) and in Figure 1.

Although ten of the replication SNPs showed a consistent direction of effect across all three studies, only two SNPs (both of which were genotyped on the Mayo-Perlegen LEAPS GWAS platforms) resulted in increased statistical evidence of association when combining the three studies, and both of these were in a recessive model. The most strongly associated SNP, rs10767971, located on chromosome 11 between the genes QSER1 and PRRG4, was associated with a 3.2 year older PD onset in individuals with 2 copies of the minor allele $(\mathrm{p}=5.4 \times 10-7$ in the 3 sample meta-analysis, compared to $4.3 \times 10-6$ in the 2 sample meta-analysis). Conversely, an estimated 6.9 year earlier age of onset $(\mathrm{p}=8.7 \times 10-6$ in the 3 sample meta-analysis compared to $9.8 \times 10-6$ in the 2 sample meta-analysis) was observed for the SNP rs7577851, located in the 16th intron of the gene AAK1 on chromosome 2.

The most highly associated SNP in both the additive and dominant three sample meta-analyses, rs17565841, is located approximately $3 \mathrm{~kb}$ from the 3 ' end of the gene OCA2 on chromosome 15 . This SNP was associated with an average 2.8 years younger onset age $\left(p=2.6 \times 10^{-6}\right)$ under an additive model and a 3.3 years younger onset age $\left(\mathrm{p}=2.1 \times 10^{-6}\right)$ under a dominant model. Inclusion of the Italian cases in the meta-analysis did not strengthen the evidence of association as compared to the results seen in the two sample meta-analyses $\left(9.1 \times 10^{-7}\right.$ for additive and $1.9 \times 10^{-6}$ for dominant). However, in the Italian replication sample, this SNP did provide modest statistical association to onset age ( $\mathrm{p}=0.05$ for additive and $\mathrm{p}=0.04$ for dominant) with the same direction of effect seen in the two other studies.

Also showing consistent directions of effect and p-values in the three-sample meta-analysis at the level of $\mathrm{p}<1 \times 10^{-}$ ${ }^{5}$ were two SNPs located in the genes DSG3 and ATF6. The SNP rs1941184, had the second best p-value identified under the dominant model and is located in the third intron of the gene DSG3 on chromosome 18. This SNP was associated with an average 2.3 year younger age of onset of PD across the three studies $\left(\mathrm{p}=4.3 \times 10^{-6}\right)$. The SNP rs10918270, located in the $15^{\text {th }}$ intron of the gene ATF6 on chromosome 1, was identified under both additive and dominant modes of inheritance, but showed stronger association in the three sample meta-analysis under the dominant model $\left(\mathrm{p}=7.5 \times 10^{-6}\right)$ with an average 2.3 year younger onset of PD. No association to age with direction of effect consistent with that observed for onset age of PD was seen in the control sample for any of the 24 SNPs at a significance level equal to 0.05 .

\section{Discussion}

We present results from the first GWAS for age at onset of PD, including a meta-analysis with the publicly available Mayo-Perlegen LEAPS GWAS data (dbGaP Study Accession: phs000048.v1.p1) and a follow-up replication study in an independent PD sample recruited in Milan, Italy. Differences were observed in the age distributions in the three populations used in this study (Table 1). However, there were no imposed age restrictions in any of the studies and a wide distribution of ages was represented in all three populations, each with a range of greater than 60 years.

No SNP reached the commonly accepted criterion for genome-wide significance of $\mathrm{p}<5 \times 10^{-8}$ [40], which is based on recent estimates of independent genomewide sequence variation to maintain 5\% genomewide type I error rate $[41,42]$. While this criterion provides an appropriate cutoff for determining significance for the large number of SNPs provided by imputation, this measure does not account for the testing of multiple genetic models, as was performed in this study. Despite the lack of genomewide significance, the meta-analysis in this study showed evidence of several interesting loci with consistent effects on onset age of PD across the three independent populations studied.

The SNP with the strongest evidence for association to onset age, rs 10767971, is associated with a later age of onset under a recessive model. This SNP is nearly equidistant between the genes PRRG4 and QSER1 on chromosome 11, at just under $20 \mathrm{~kb}$ from each. The association results for nearby SNPs studied in the meta-analysis of the two GWAS as well as the LD structure and recombination rates for the region are shown in Figure 2A and 2B under 
Table 2: Location and minor allele frequency (MAF) information for 24 SNPs selected for replication study in Italian sample

\begin{tabular}{|c|c|c|c|c|c|}
\hline Chr & SNP & SNP position ${ }^{\mathrm{a}}$ & Minor Allele & MAF & Genes in Region ${ }^{b}$ \\
\hline 1 & rs7556447 & $2,335,959$ & G & 0.24 & PEXIO \\
\hline I & rs $1355637 \mathrm{c}$ & $148,849,062$ & $\mathrm{~T}$ & 0.19 & $M C L I \mid E N S A$ \\
\hline I & rs 10918270 & $160,182,125$ & $A$ & 0.41 & ATF6 \\
\hline 2 & rs 11899121 & $20,231,454$ & C & 0.50 & SDCI \\
\hline 2 & rs $757785 I^{c}$ & $69,577,214$ & $\mathrm{~T}$ & 0.17 & $A A K I$ \\
\hline 2 & rs 17817190 & $134,068,1 \mid 8$ & G & 0.11 & NAP5 \\
\hline 6 & rs6936388 & $42,275,464$ & $\mathrm{~T}$ & 0.25 & CCND3|TAF8|GUCA IA|GUCA IB|MRPSIO \\
\hline 6 & rsI572662 & $154,853,289$ & A & 0.36 & CNKSR3|CLDN20|RBMI6|TIAM2|TFB IM \\
\hline 7 & $\mathrm{rs} \mid 420143^{c}$ & $29,514,849$ & $\mathrm{C}$ & 0.44 & CHN2 \\
\hline 7 & rs 17663983 & $76,243,177$ & $\mathrm{~T}$ & 0.12 & \\
\hline 10 & rs 12261736 & $52,738,610$ & $\mathrm{~T}$ & 0.28 & PRKGI \\
\hline 10 & rs7076519 & $127,738,829$ & C & 0.33 & $A D A M / 2$ \\
\hline 11 & rsl076797|c & $32,852,240$ & $\mathrm{~T}$ & 0.42 & PRRG4|QSERI \\
\hline 12 & rs 12829697 & $30,067,223$ & G & 0.13 & \\
\hline 12 & rs 10773917 & $130,572,784$ & $\mathrm{~T}$ & 0.23 & \\
\hline 13 & rs $4771006^{d}$ & $26,180,684$ & $A$ & 0.49 & WASF3 \\
\hline 13 & rs676495c & $29,561,754$ & $\mathrm{~T}$ & 0.24 & \\
\hline 14 & rs10147486 & $47,054,769$ & $\mathrm{~T}$ & 0.27 & MDGA2 \\
\hline 15 & rs $1756584 \mid$ & $25,670,842$ & $A$ & 0.10 & OCA2 \\
\hline 17 & rs9904572 & $12,803,084$ & $A$ & 0.34 & $\mathrm{RICH} 2$ \\
\hline 17 & rs479|57|c & $|4| 55,,80 \mid$ & $A$ & 0.42 & HS3ST3BI \\
\hline 18 & rs194II84 & $27,292,121$ & C & 0.30 & DSG3 \\
\hline 19 & rs 10420134 & $40,953,768$ & G & 0.18 & C19orf55|SNX26 \\
\hline 20 & rs3887942 & $23,925,072$ & G & 0.19 & GGTLCI \\
\hline
\end{tabular}

a From NCBI Build 36 reference; b Nearest genes within 100 kb of SNP;c SNP was genotyped in Mayo-Perlegen LEAPS GWAS; d SNP was genotyped in GenePD-PROGENI GWAS

recessive and dominant models. While the strongest evidence of association appeared with a recessive model, many nearby SNPs in strong LD showed similar association under the dominant model. The pattern suggests a single association, spanning several SNPs that may be more evident around the PRRG4 gene and may extend toward the CCDC73 and EIF3M genes.
The SNP showing the strongest association to PD onset across the three populations under both the additive and dominant models lies $3 \mathrm{~kb}$ from the 3 ' end of the gene OCA2 (oculocutaneous albinism II). Mutations in OCA2 are responsible for the most common form of albinism, oculocutaneous albinism type 2 [43] and several studies have shown this gene to be associated with common skin, hair and eye color variation found in European popula- 
Table 3: Additive model study-specific and meta-analysis results

\begin{tabular}{|c|c|c|c|c|c|c|c|c|c|c|c|c|}
\hline \multirow[b]{2}{*}{ SNP } & \multicolumn{2}{|c|}{ GenePD-PROGENI } & \multicolumn{2}{|c|}{$\begin{array}{l}\text { Mayo-Perlegen } \\
\text { LEAPS }\end{array}$} & \multicolumn{3}{|c|}{ GWAS Meta-analysis } & \multicolumn{2}{|c|}{ Milan, Italian } & \multicolumn{3}{|c|}{ Three Sample Meta-analysis } \\
\hline & effect & p-value & effect & p-value & $\begin{array}{l}\text { Direction } \\
\text { of Effect }\end{array}$ & effect & p-value & effect & p-value & $\begin{array}{l}\text { Direction } \\
\text { of Effect }\end{array}$ & effect & p-value \\
\hline rs|756584| & -4.66 & $2.7 \times 10^{-6}$ & -3.64 & $1.7 \times 10^{-1}$ & -- & -4.53 & $9.1 \times 10^{-7}$ & -1.57 & $5.0 \times 10^{-2}$ & --- & -2.84 & $2.6 \times 10^{-6}$ \\
\hline rs 10918270 & -2.12 & $1.1 \times 10^{-4}$ & -1.90 & $1.6 \times 10^{-2}$ & -- & -2.05 & $4.8 \times 10^{-6}$ & -0.62 & $2.7 \times 10^{-1}$ & --- & -1.49 & $2.0 \times 10^{-5}$ \\
\hline rs 12261736 & -3.61 & $1.8 \times 10^{-7}$ & -1.17 & $4.0 \times 10^{-1}$ & -- & -3.13 & $3.5 \times 10^{-7}$ & -0.42 & $4.5 \times 10^{-1}$ & --- & -1.65 & $6.6 \times 10^{-5}$ \\
\hline rs4771006 & 2.35 & $1.6 \times 10^{-3}$ & 2.59 & $1.6 \times 10^{-3}$ & ++ & 2.46 & $7.3 \times 10^{-6}$ & 0.50 & $3.8 \times 10^{-1}$ & +++ & 1.52 & $1.2 \times 10^{-4}$ \\
\hline rs 1420143 & 2.08 & $1.4 \times 10^{-4}$ & 2.58 & $8.1 \times 10^{-3}$ & ++ & 2.20 & $3.6 \times 10^{-6}$ & 0.02 & $9.8 \times 10^{-1}$ & +++ & 1.27 & $4.1 \times 10^{-4}$ \\
\hline rs6936388 & 2.45 & $4.2 \times 10^{-4}$ & 2.98 & $7.2 \times 10^{-3}$ & ++ & 2.60 & $9.2 \times 10^{-6}$ & -0.31 & $7.0 \times 10^{-1}$ & ++- & 1.58 & $8.2 \times 10^{-4}$ \\
\hline rs10147486 & 2.21 & $3.1 \times 10^{-4}$ & 2.89 & $8.0 \times 10^{-4}$ & ++ & 2.44 & $9.2 \times 10^{-7}$ & -0.69 & $3.0 \times 10^{-1}$ & ++- & 1.31 & $9.5 \times 10^{-4}$ \\
\hline rs7076519 & $-2.7 I$ & $9.3 \times 10^{-6}$ & -2.53 & $2.5 \times 10^{-2}$ & -- & -2.67 & $6.0 \times 10^{-7}$ & 0.68 & $1.8 \times 10^{-1}$ & --+ & -0.92 & $1.3 \times 10^{-2}$ \\
\hline
\end{tabular}

tions [43-48]. Variations in OCA2 have been associated with susceptibility to melanoma [49], which has also been reported to occur with increased frequency among PD cases [50-52]. Because of the targeted degradation of pigmented neurons in PD brains, these associations have lead to a hypothesized link between genes involved in pigmentation, such as OCA2, and PD, likely mediated through common elements in melanin and neuromelanin synthesis[53]. The protein encoded by OCA2, 'P' protein, is involved in the transport of tyrosine, a precursor to melanin, as well as in the regulation of melanosomal $\mathrm{pH}$ which may be key to the initiation of the enzyme controlling melanin synthesis in melanocytes [54]. It is not clear whether synthesis of neuromelanin is also regulated

Table 4: Dominant model study-specific and meta-analysis results

\begin{tabular}{|c|c|c|c|c|c|c|c|c|c|c|c|c|}
\hline \multirow[b]{2}{*}{ SNP } & \multicolumn{2}{|c|}{ GenePD-PROGENI } & \multicolumn{2}{|c|}{$\begin{array}{l}\text { Mayo-Perlegen } \\
\text { LEAPS }\end{array}$} & \multicolumn{3}{|c|}{ GWAS Meta-analysis } & \multicolumn{2}{|c|}{ Milan, Italian } & \multicolumn{3}{|c|}{ Three Sample Meta-analysis } \\
\hline & effect & p-value & effect & p-value & $\begin{array}{l}\text { Direction } \\
\text { of Effect }\end{array}$ & effect & p-value & effect & p-value & $\begin{array}{l}\text { Direction } \\
\text { of Effect }\end{array}$ & effect & p-value \\
\hline rs|756584| & -5.08 & $4.7 \times 10^{-6}$ & -3.68 & $2.0 \times 10^{-1}$ & -- & -4.90 & $1.9 \times 10^{-6}$ & -1.94 & $3.6 \times 10^{-2}$ & --- & -3.26 & $2.1 \times 10^{-6}$ \\
\hline rs194II84 & -2.94 & $1.3 \times 10^{-4}$ & -2.94 & $1.0 \times 10^{-2}$ & -- & -2.94 & $3.7 \times 10^{-6}$ & -1.25 & $1.2 \times 10^{-1}$ & --- & -2.28 & $4.3 \times 10^{-6}$ \\
\hline rs 10918270 & -3.26 & $2.9 \times 10^{-5}$ & -2.74 & $1.5 \times 10^{-2}$ & -- & -3.09 & $1.2 \times 10^{-6}$ & -0.87 & $2.9 \times 10^{-1}$ & --- & -2.26 & $7.5 \times 10^{-6}$ \\
\hline rs3887942 & 4.17 & $7.2 \times 10^{-4}$ & 7.10 & $1.5 \times 10^{-3}$ & ++ & 4.85 & $6.4 \times 10^{-6}$ & 0.93 & $2.6 \times 10^{-1}$ & +++ & 2.37 & $2.7 \times 10^{-4}$ \\
\hline rs 12261736 & -4.03 & $9.5 \times 10^{-6}$ & -2.04 & $2.8 \times 10^{-1}$ & -- & -3.66 & $7.3 \times 10^{-6}$ & -0.46 & $5.7 \times 10^{-1}$ & --- & -2.07 & $3.5 \times 10^{-4}$ \\
\hline rs 10773917 & 3.15 & $3.8 \times 10^{-5}$ & 2.58 & $3.5 \times 10^{-2}$ & ++ & 2.99 & $3.7 \times 10^{-6}$ & -0.13 & $8.7 \times 10^{-1}$ & ++- & 1.75 & $4.8 \times 10^{-4}$ \\
\hline rs 10420134 & -3.21 & $5.8 \times 10^{-5}$ & -3.12 & $5.1 \times 10^{-2}$ & -- & -3.19 & $7.1 \times 10^{-6}$ & 0.56 & $5.1 \times 10^{-1}$ & --+ & -1.67 & $2.3 \times 10^{-3}$ \\
\hline rs9904572 & 3.57 & $4.3 \times 10^{-6}$ & 2.72 & $6.4 \times 10^{-2}$ & ++ & 3.38 & $7.2 \times 10^{-7}$ & -1.05 & $1.9 \times 10^{-1}$ & ++- & 1.55 & $3.1 \times 10^{-3}$ \\
\hline rs 17817190 & -3.87 & $3.9 \times 10^{-5}$ & -5.27 & $2.1 \times 10^{-2}$ & -- & -4.07 & $2.5 \times 10^{-6}$ & 1.30 & $2.1 \times 10^{-1}$ & --+ & -1.85 & $5.3 \times 10^{-3}$ \\
\hline rs I572662 & 3.57 & $4.1 \times 10^{-5}$ & 4.89 & $7.5 \times 10^{-2}$ & ++ & 3.69 & $7.8 \times 10^{-6}$ & -0.67 & $4.1 \times 10^{-1}$ & ++- & 1.45 & $1.2 \times 10^{-2}$ \\
\hline rs7076519 & -3.73 & $1.2 \times 10^{-5}$ & -3.81 & $3.0 \times 10^{-2}$ & -- & -3.74 & $9.3 \times 10^{-7}$ & 1.48 & $6.2 \times 10^{-2}$ & --+ & -1.23 & $2.6 \times 10^{-2}$ \\
\hline
\end{tabular}


Table 5: Recessive model study-specific and meta-analysis results

\begin{tabular}{|c|c|c|c|c|c|c|c|c|c|c|c|c|}
\hline \multirow[b]{2}{*}{ SNP } & \multicolumn{2}{|c|}{ GenePD-PROGENI } & \multicolumn{2}{|c|}{$\begin{array}{l}\text { Mayo-Perlegen } \\
\text { LEAPS }\end{array}$} & \multicolumn{3}{|c|}{ GWAS Meta-analysis } & \multicolumn{2}{|c|}{ Milan, Italian } & \multicolumn{3}{|c|}{ Three Sample Meta-analysis } \\
\hline & effect & p-value & effect & p-value & $\begin{array}{l}\text { Direction } \\
\text { of Effect }\end{array}$ & effect & p-value & effect & p-value & $\begin{array}{l}\text { Direction } \\
\text { of Effect }\end{array}$ & effect & p-value \\
\hline rs 1076797| & 4.23 & $9.3 \times 10^{-6}$ & 2.35 & $1.3 \times 10^{-1}$ & ++ & 3.71 & $4.3 \times 10^{-6}$ & 2.40 & $2.6 \times 10^{-2}$ & +++ & 3.24 & $5.4 \times 10^{-7}$ \\
\hline rs757785। & -8.64 & $1.2 \times 10^{-4}$ & -8.03 & $3.1 \times 10^{-2}$ & -- & -8.48 & $9.8 \times 10^{-6}$ & -3.89 & $1.3 \times 10^{-1}$ & --- & -6.85 & $8.7 \times 10^{-6}$ \\
\hline rs|355637 & -5.10 & $2.3 \times 10^{-3}$ & -14.25 & $4.1 \times 10^{-5}$ & -- & -6.83 & $5.1 \times 10^{-6}$ & 1.10 & $6.0 \times 10^{-1}$ & --+ & -4.19 & $6.2 \times 10^{-4}$ \\
\hline rsl|899|2I & -3.41 & $8.0 \times 10^{-5}$ & -3.33 & $1.6 \times 10^{-2}$ & -- & -3.39 & $3.5 \times 10^{-6}$ & 0.43 & $6.5 \times 10^{-1}$ & --+ & -1.99 & $6.3 \times 10^{-4}$ \\
\hline rs I 2829697 & $-|0.5|$ & $8.5 \times 10^{-5}$ & -10.33 & $3.0 \times 10^{-2}$ & -- & -10.47 & $7.0 \times 10^{-6}$ & 0.68 & $8.1 \times 10^{-1}$ & --+ & -6.15 & $7.2 \times 10^{-4}$ \\
\hline rs|7663983 & -16.72 & $1.2 \times 10^{-5}$ & -25.53 & $4.6 \times 10^{-1}$ & -- & -16.83 & $8.1 \times 10^{-6}$ & 5.77 & $2.9 \times 10^{-1}$ & --+ & -9.46 & $2.3 \times 10^{-3}$ \\
\hline rs 12261736 & -8.48 & $1.9 \times 10^{-6}$ & -0.56 & $8.9 \times 10^{-1}$ & -- & -7.14 & $9.6 \times 10^{-6}$ & -0.73 & $4.9 \times 10^{-1}$ & --- & -2.65 & $2.7 \times 10^{-3}$ \\
\hline rsl420I43 & 3.31 & $7.9 \times 10^{-4}$ & 6.05 & $1.3 \times 10^{-3}$ & ++ & 3.90 & $7.3 \times 10^{-6}$ & -0.52 & $5.9 \times 10^{-1}$ & ++ & 1.89 & $3.3 \times 10^{-3}$ \\
\hline rs676495 & -6.90 & $1.9 \times 10^{-5}$ & -11.27 & $2.4 \times 10^{-1}$ & -- & -7.02 & $9.1 \times 10^{-6}$ & 1.86 & $2.7 \times 10^{-1}$ & --+ & -2.84 & $1.4 \times 10^{-2}$ \\
\hline rs7556447 & -13.34 & $2.1 \times 10^{-5}$ & -11.11 & $1.9 \times 10^{-1}$ & -- & -13.08 & $7.9 \times 10^{-6}$ & -0.44 & $7.7 \times 10^{-1}$ & --- & -3.01 & $2.3 \times 10^{-2}$ \\
\hline rs479|57| & -5.18 & $1.3 \times 10^{-5}$ & -6.39 & $2.4 \times 10^{-1}$ & -- & -5.23 & $5.9 \times 10^{-6}$ & 2.57 & $3.5 \times 10^{-2}$ & --+ & -1.52 & $6.9 \times 10^{-2}$ \\
\hline
\end{tabular}

through melanosomal $\mathrm{pH}$ or is affected by the ' $\mathrm{P}$ ' protein in a similar way [55]. Nevertheless, the association between OCA2 and younger age of onset are suggestive of a neuromelanin-related mechanism of effect.

The association of an intronic SNP in the gene DSG3 (desmoglein 3 (pemphigus vulgaris antigen)) may also be indicative of a neuromelanin related effect on onset age of PD. The protein encoded by DSG3 is the autoantigen for the autoimmune skin disease pemphigus vulgaris and this gene is expressed primarily in skin. Interestingly, some reports have demonstrated increased expression of DSG3 in melanocytes compared to keratinocytes (the most common cell type in the epidermis) [56].

An intronic SNP in the gene ATFG also showed strong association to earlier age of onset of PD. ATFG (activating transcription factor 6) transcribes a transcription factor localized to the endoplasmic reticulum (ER). The ATF6 protein is a critical regulator of the unfolded protein response (UPR), a highly conserved pathway activated in response to ER stress, and is a protective cellular response to the accumulation of misfolded proteins [57-59]. The UPR has been implicated in neurotoxin based cellular models of PD [60] and has also been shown to be activated by the over-expression of $\alpha$-synuclein in yeast cells [61]. More recently, postmortem studies of PD case and control brains have shown activation of the UPR in cases, but not controls and that this activation is associated with the aggregation of $\alpha$-synuclein [62].

The finding of an intronic SNP in AAK1 associated with $P D$ onset age is intriguing because of the gene's genomic location, its function, and its close relation to a gene identified for PD susceptibility. The AAK1 (AP2 associated kinase 1) gene is located on chromosome 2p14, near 2 p13, which has previously been implicated as the PARK3 locus[63], and for which linkage to onset age was demonstrated in both the GenePD [64] and PROGENI [65] studies. The $A A K 1$ gene itself has not been previously implicated by positional mapping, but a microarray study of PD brain compared to controls demonstrated differential expression of $A A K 1$ [66]. In our past GWAS of PD susceptibility in the GenePD-PROGENI cohort [20], the region containing the gene GAK (cyclin G-associated kinase) had the strongest evidence for association (chromosome 4p). The AAK1 and GAK genes both function at multiple steps in clathrin-mediated vesicular transport and the two kinases likely have some redundant functions [67] related to their homologous serine/threonine-kinase domain [68]. Recently, cathepsin D was implicated as the main lysosomal enzyme involved in $\alpha$-synuclein degredation [69], and depletion of GAK was shown to impair the lysosomal sorting of cathepsin D [68]. Thus, the finding 

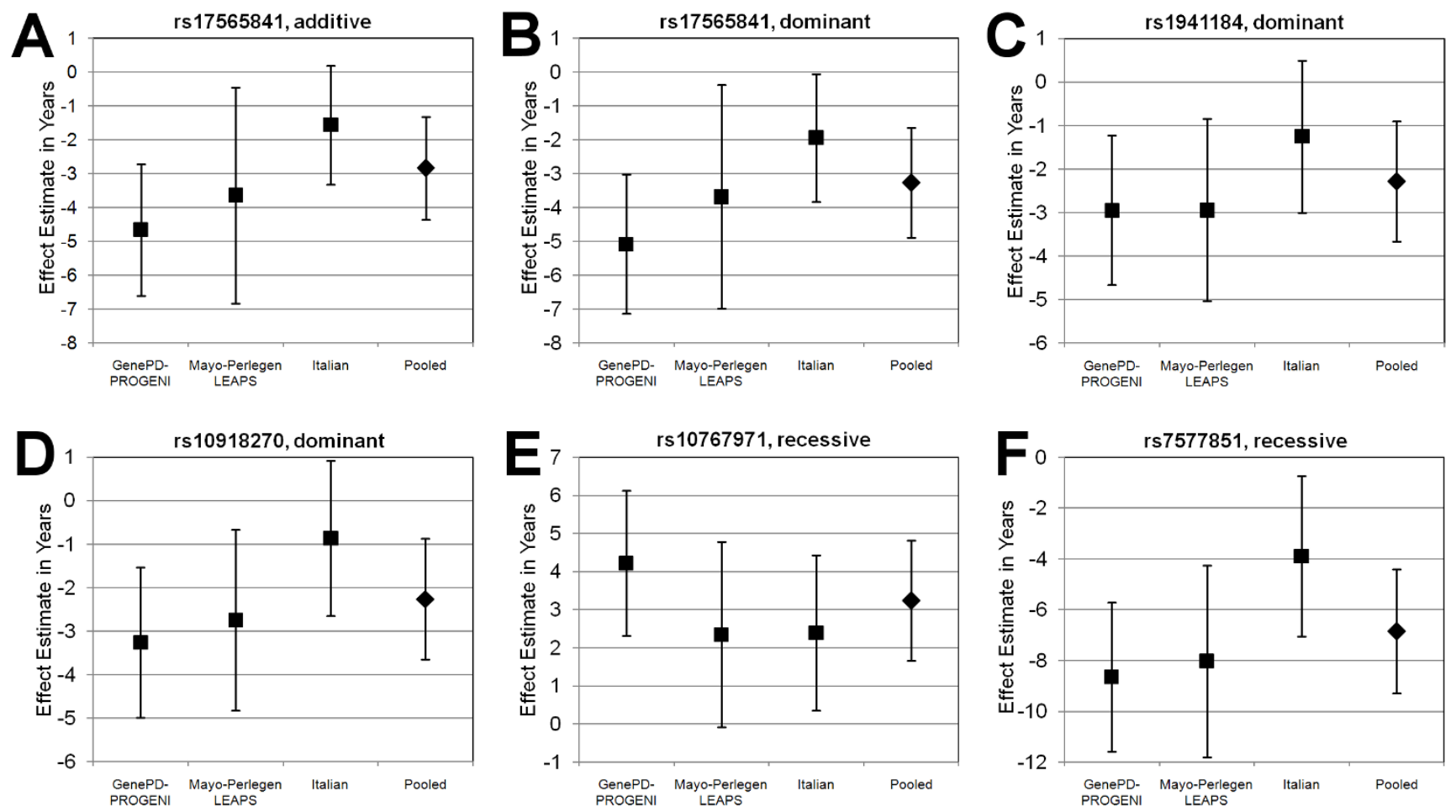

\section{Figure I}

Forest plots showing study-specific and pooled effects for top six results in final meta-analysis. The effect (in years) on age at PD onset and $95 \%$ confidence intervals for the indicated genetic model are shown for each of the three independent samples and the combined analysis. A. Additive model of the A allele in SNP rs I756584I B. Dominant model of the A allele in SNP rs I756584I C. Dominant model of the C allele in SNP rs I94 I I 84 D. Dominant model of the A allele in SNP rs I0918270 E. Recessive model of the T allele in SNP rs I076797I F. Recessive model of the T allele in SNP rs757785I.

that $A A K 1$ influences onset age and GAK influences risk in familial PD suggest that pathways involving lysosomal activity influence PD risk.

Several previous genome scans have provided evidence of loci linked to onset age, including 2p13 seen in both the GenePD and PROGENI studies, as mentioned above. Evidence of linkage has also been reported on chromosomes $1 p, 1 q, 8 q, 9 q, 10 q, 20$ and $21[64,65,70]$, but there is little overlap between these linkage regions and our top metaanalysis association results. Aside from the identification of the AAK1 gene near 2p13, the strongest association result observed under one of the previously reported linkage regions occurs near the gene sortilin-related VPS10 domain containing receptor 3 (SORCS3) located near the LOD score peak at $10 \mathrm{q}$, originally identified in a combined linkage scan of onset age in PD and Alzheimer's disease [70]. This association is seen most strongly under a dominant model $\left(\mathrm{p}=2.5 \times 10^{-5}\right)$ with minor allele carriers having an estimated older onset age by 3.3 years (see Additional file 1: Table S2).

A final region of interest is $15 \mathrm{q} 26.2$ that includes the gene MCTP2. Several SNPs in this region showed association to earlier onset age of PD in the meta-analysis of the two GWAS under the recessive model (see Additional file 1: Table S3). These SNPs did not reach the criteria for inclusion in the replication study, as the strongest p-value seen was $2.2 \times 10^{-5}$ with $\mathrm{rs} 17504636$. This SNP was associated with a 9.2 year earlier average PD onset. This region overlaps with a SNP reported in the susceptibility GWAS including these cases [20]. In that study the SNP rs4476132 was associated with PD susceptibility with an odds ratio of $1.3\left(\mathrm{p}=7.7 \times 10^{-5}\right.$ - meta-analysis with additive model). This overlap is consistent with a locus associated with a risk for younger-onset PD or with an effect modifying age dependent penetrance. The gene in this region, MCTP2 (multiple $\mathrm{C} 2$ domains, transmembrane $2)$, is expressed in the brain and has been implicated in linkage and association studies of abdominal fat [71] and major depression [72].

Important distinctions can be made between those genes that influence susceptibility for developing disease, and the genetic modifiers that influence penetrance or, as studied here, onset age. Perhaps the best examples for genetic modifiers are seen for Huntington's disease (HD) where an expanded CAG trinucleotide repeat on chromosome 4p16.3 
A

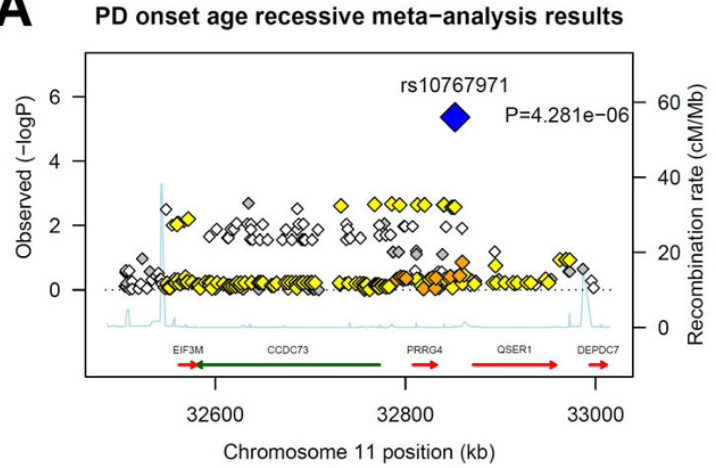

B PD onset age dominant meta-analysis results

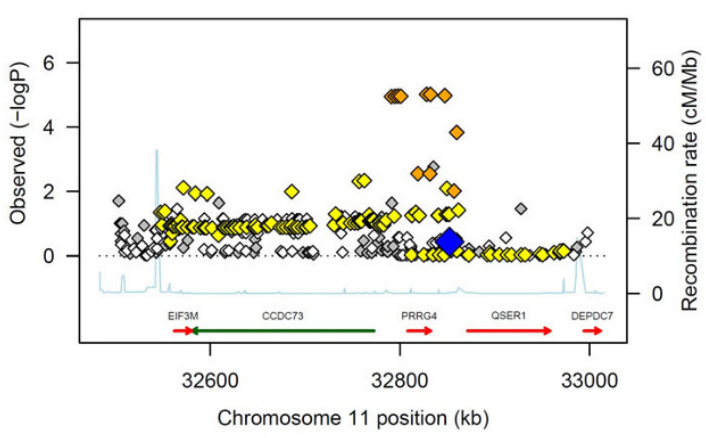

Figure 2

Evidence of association in Chromosome I I region. Along the $\mathrm{x}$ axis is the physical position in the region (in $\mathrm{kB}$ ) with known genes shown in their orientation The left $Y$-axis denotes the association test result as -log( $P$-value) corresponding to diamonds in the figure. The blue diamond identifies the primary SNP result labeled with an rs\# and $p$-value. The color of additional diamonds depicts the pairwise linkage disequilibrium with the primary SNP: red indicates $r^{2}>0.8$, orange $0.5<r^{2}<0.8$, yellow $0.2<r^{2}<0.5$, white $r^{2}<0.2$, grey unknown LD. $R^{2}$ values were obtained from the CEPH HapMap data. The right $Y$-axis indicates the recombination rate, also obtained from CEPH HapMap data, and shown within the figure by the solid light-blue line. A. Recessive model B. Dominant model.

causes the disease, but wide variation in onset age is evident for individuals with identical repeat lengths. The identification of the genes that presumably interact with huntingtin to produce relatively younger or older onset for a given repeat size provide insight into the pathogenic mechanisms for $\mathrm{HD}$, as well as therapeutic targets for intervention [73-75]. Similarly, identifying those genes and their products that are associated with older onset in PD may provide insight into the disease mechanisms and processes for delaying onset with implications for novel treatments.

\section{Conclusion}

The identification of the $15 \mathrm{q} 26.2$ region as well as the related genes $A A K 1$ and $G A K$ in the studies of PD onset age and susceptibility highlights the importance of the continued study of both of these traits, both separately and in combination. The direct overlap in affection and onset age association results in the $15 \mathrm{q} 26.2$ region shows this to be a candidate region that would benefit from further examination with consideration of important agerelated effects, for example in studies correlating expression of genes in this region with onset age. The identification of association to onset age with the gene $A A K 1$, in the same pathway as a previously identified susceptibilityassociated gene GAK highlights the importance of genetic pathways in PD etiology, showing that the genes along the same pathway may have redundant effects or may modify disease pathology different ways, observed by differences in disease onset and progression. Studying PD in the context of onset age provides fundamental insight into the disease process and is essential to understanding mechanisms that modify disease penetrance and therefore may be key in identifying therapeutic targets.

\section{Competing interests}

The authors declare that they have no competing interests.

\section{Authors' contributions}

JCL participated in conception and design of the study, conducted statistical analyses, participated in the interpretation of data, and drafted the manuscript. NP, AD and JBW participated in the conception and design of the study, conducted statistical analyses, participated in the interpretation of data, and revised the article critically for important intellectual content. SG, GP, CBM, ALD, CH, JFG, WCN, RHM, and TF participated in the conception and design of the study, participated in the interpretation of data, and revised article critically for important intellectual content. All authors read and approved the final manuscript.

\section{Additional material}

\section{Additional file 1}

Supplementary Tables. The excel file includes three supplementary tables. Supplementary Table S1 includes regions showing associations at $p<$ 0.0001 for the additive model GWAS meta-analysis and study-specific results. Supplementary Table S2 includes regions showing associations at $p<0.0001$ for the dominant model GWAS meta-analysis and study-specific results. Supplementary Table S3 includes Regions showing associations at $p<0.0001$ for the recessive model GWAS meta-analysis and study-specific results

Click here for file

[http://www.biomedcentral.com/content/supplementary/14712350-10-98-S1.XLS] 


\section{Acknowledgements}

This project was supported by R0I NS37I67, R0I NS0367II, the Robert P. \& Judith N. Goldberg Foundation, the Bumpus Foundation and the Harvard NeuroDiscovery Center. This study used samples from the NINDS Human Genetics Resource Center DNA and Cell Line Repository http:// ccr.coriell.org/ninds, as well as clinical data.

DNA samples contributed by the Parkinson Institute - Istituti Clinici di Perfezionamento, Milan, Italy were from the "Human genetic bank of patients affected by PD and parkinsonisms", supported by Italian Telethon grant $\mathrm{n}$. GTB0700I and by the "Fondazione Grigioni per il Morbo di Parkinson".

A portion of this research was conducted using the Linux Cluster for Genetic Analysis (LinGA-II) funded by the Robert Dawson Evans Endowment of the Department of Medicine at Boston University School of Medicine and Boston Medical Center.

Genotyping services were provided by the Center for Inherited Disease Research (CIDR). CIDR is fully funded through a federal contract from the National Institutes of Health to The Johns Hopkins University, contract number HHSN268200782096C. We particularly thank Drs. Kimberly Doheny and Elizabeth Pugh from CIDR and Mr. Justin Paschall from NCBI for their assistance.

The data used in this study is available at http://www.ncbi.nlm.nih.gov/sites/ entrez? db=gap through dbGaP accession number: phs000 I26.vl.pl.

Funding support for the Mayo-Perlegen LEAPS (Linked Efforts to Accelerate Parkinson's Solutions) Collaboration Study was provided by the Michael J. Fox Foundation. Additional support was provided by the NIH grants ESI 075 I and NS33978. The datasets used for the analyses described in this manuscript were obtained from $\mathrm{dbGaP}$ found at http://

www.ncbi.nlm.nih.gov/projects/gap/cgi-bin/

study.cgi?study id=phs000048.vl.pl through dbGaP study accession numbers phs000048. Data for the Mayo-Perlegen LEAPS Collaboration Study were provided by Demetrius M. Maraganore, MD on behalf of his collaborators at the Mayo Clinic and at Perlegen Sciences, Inc.

The following are members of the PROGENI Steering Committee. University of Tennessee Health Science Center: R. F. Pfeiffer; University of Rochester: F. Marshall, D. Oakes, A. Rudolph, A. Shinaman; Columbia University Medical Center: K. Marder; Indiana University School of Medicine: P.M. Conneally, T. Foroud, C. Halter; University of Kansas Medical Center: K. Lyons; Eli Lilly \& Company: E. Siemers; Medical College of Ohio: L. Elmers; University of California, Irvine: N. Hermanowicz.

The following are members of the GenePD Steering Committee. University of Virginia Health System: G.F. Wooten; UMDNJ-Robert Wood Johnson Medical School: L. Golbe; Center for Human Genetic Research, Massachusetts General Hospital, Harvard Medical School: J.F. Gusella; Boston University School of Medicine: R.H. Myers.

We thank the subjects for their participation in this research study.

\section{PSG-PROGENI Investigators and Coordinators: Albany Medical} College: S Factor, D Higgins, S Evans; Barrow Neurological Institute: H Shill, M Stacy, J Danielson, L Marlor, K Williamson; Baylor College of Medicine: J Jankovic, C Hunter; Beth Israel Deaconess Medical Center: D Simon, P Ryan, L Scollins; Beth Israel Medical Center: R Saunders-Pullman, K Boyar, C Costan-Toth, E Ohmann; Brigham \& Women's Hospital: L Sudarsky, C Joubert; Brown University (Memorial Hospital of RI): J Friedman, K Chou, H Fernandez, M Lannon; Cleveland Clinic Florida-Weston: N Galvez-
Jimenez, A Podichetty, K Thompson; Clinical Neuroscience Center: P Lewitt, M DeAngelis; Colorado Neurological Institute: C O'Brien, L Seeberger, $C$ Dingmann, D Judd; Columbia University Medical Center: $\mathrm{K}$ Marder, J Fraser, J Harris; Creighton University: J Bertoni, C Peterson; Evanston Northwestern Healthcare: M Rezak, G Medalle; Hotel-Dieu Hospital-Chum: S Chouinard, M Panisset, J Hall, H Poiffaut; Hunter Homes McGuire Veterans Medical Center: V Calabrese, P Roberge; Indiana University School of Medicine: J Wojcieszek, J Belden; Institute For Neurodegenerative Disorders: D Jennings, K Marek, S Mendick; Johns Hopkins University: S Reich, B Dunlop; London Health Sciences Centre: M Jog, C Horn; Mayo Clinic Jacksonville: R Uitti, M Turk; McFarland Neurosciences: T Ajax, J Mannetter; Medical College of Georgia: K Sethi, J Carpenter, B Dill, L Hatch, K Ligon, S Narayan; Medical College of Wisconsin: K Blindauer, K Abou-Samra, J Petit; Medical University of Ohio: L Elmer, E Aiken, K Davis, C Schell, S Wilson; Mount Sinai School of Medicine: M Velickovic, W Koller (deceased), S Phipps; North Shore-LIJ Health System: A Feigin, M Gordon, J Hamann, E Licari, M Marotta-Kollarus, B Shannon, R Winnick; Northwestern University: T Simuni, A Videnovic, A Kaczmarek, K Williams, M Wolff; Ochsner Clinic Foundation: J Rao, M Cook; Ohio State University: M Fernandez, S Kostyk, J Hubble, A Campbell, C Reider, A Seward; Oregon Health \& Science University: R Camicioli, J Carter, J Nutt, P Andrews, S Morehouse, C Stone; Ottawa Hospital Civic Site: T Mendis, D Grimes, C Alcorn-Costa, P Gray, K Haas, J Vendette; Pacific Neuroscience Medical Group: J Sutton, B Hutchinson, J Young; Saskatoon Dist Health Board Royal Univ Hosp: A Rajput, A Rajput, L Klassen, T Shirley; Scott \& White Hospital/Texas A\&M University: B Manyam, P Simpson, J Whetteckey, B Wulbrecht; The Parkinson's \& Movement Disorder Institute: D Truong, M Pathak, K Frei, N Luong, T Tra, A Tran, J Vo; Toronto Western Hospital, University Health: A Lang, G Kleiner-Fisman, A Nieves, L Johnston, J So; UMDNJ-School of Osteopathic Medicine: G Podskalny, L Giffin; University of Alabama at Birmingham: P Atchison, C Allen; University of Alberta: W Martin, M Wieler; University of Calgary: $O$ Suchowersky, M Klimek; University of California Irvine: N Hermanowicz, S Niswonger; University of California San Diego: C Shults (deceased), D Fontaine; University of California San Francisco: M Aminoff, C Christine, M Diminno, J Hevezi; University of Chicago: A Dalvi, U Kang, J Richman, S Uy, J Young; University of Cincinnati: A Dalvi, A Sahay, M Gartner, D Schwieterman; University of Colorado Health Sciences Center: D Hall, M Leehey, S Culver, T Derian; University of Connecticut: T Demarcaida, S Thurlow; University of lowa: R Rodnitzky, J Dobson; University of Kansas Medical Center: K Lyons, R Pahwa, T Gales, S Thomas; University of Maryland School of Medicine: L Shulman, S Reich, W Weiner, K Dustin; University of Miami: K Lyons, C Singer, W Koller (deceased), W Weiner, L Zelaya; University of Minnesota: $P$ Tuite, $V$ Hagen, S Rolandelli, R Schacherer, J Kosowicz; University of New Mexico: P Gordon, J Werner; University of Puerto Rico School of Medicine: C Serrano, S Roque; University of Rochester: R Kurlan, D Berry, I Gardiner; University of South Florida: R Hauser, J Sanchez-Ramos, T Zesiewicz, H Delgado, K Price, P Rodriguez, S Wolfrath; University of Tennessee Health Science Center: R Pfeiffer, L Davis, B Pfeiffer; University of Texas Southwestern Medical Center: R Dewey, B Hayward, A Johnson, M Meacham, B Estes; Wake Forest University School of Medicine: F Walker, V Hunt, C O'Neill; Washington University: B Racette, L Good, M Rundle

PROGENI Molecular Genetic Laboratory: Division of Human Genetics, Cincinnati Children's Hospital Medical Center: Michael W. Pauciulo, Diane K. Marek, Veronika E. Elsaesser

GenePD Investigators and Coordinators: University Southern California School of Medicine: M. Lew; University of Calgary: O. Suchowersky, S. Furtado; University of Lübeck, Germany: C. Klein; UMDNJ-Robert Wood Johnson Medical School: L. Golbe, M.H. Mark; Massachusetts Gen- 
eral Hospital, Harvard Medical School: J. Growdon, N. Huggins; University of Virginia Health System: G.F. Wooten; University of Alabama at Birmingham: R. Watts; University of Toronto: M. Guttman; Washington University School of Medicine: B. Racette, J. PerImutter; Barrow Neurological Institute: L. Marlor, Sun Health Research Institute: H. Shill; University of Miami: C. Singer; Boston University School of Medicine: M.H. Saint-Hilaire, T. Massood; Cleveland Clinic Foundation: K. Baker, I. Itin, A. Ahmed; University of Louisville School of Medicine: I. Litvan; University of Sydney ANZAC Research Institute, Concord Hospital, Sydney, Australia: G. Nicholson, A. Corbett; Struthers Parkinson's Center, Minneapolis: M. Nance; Port City Neurology, Scarborough, ME: E. Drasby; Parkinson's Disease and Movement Disorder Center of Boca Raton: S. Isaacson; Newcastle University, Newcastle upon Tyne, UK: D. Burn, P. Chinnery; General Regional Hospital Bolzano, Bolzano, Italy: P. Pramstaller; University of Arkansas for Medical Sciences: J. Al-hinti; Aarhus University Hospital, Aarhus, Denmark: A. Moller, K. Ostergaard; University of Arizona: S. Sherman; Auckland City Hospital, Auckland, New Zealand: R. Roxburgh, B. Snow; University of Kentucky College of Medicine: J. Slevin, F. Cambi.

\section{GenePD Molecular Genetics Laboratories: Center for Human} Genetic Research, Massachusetts General Hospital, Harvard Medical School: M.E. McDonald, M. Sun, L. Mysore, M.A, Anderson, D. Lucente; Neurogenetics Laboratory, Boston University School of Medicine: S. Williamson, M.W. Nagle, B. Brandler.

\section{References}

I. Mayeux R: Epidemiology of neurodegeneration. Annual review of neuroscience 2003, 26:8I-104.

2. Schrag A, Ben-Shlomo Y, Brown R, Marsden CD, Quinn N: Youngonset Parkinson's disease revisited--clinical features, natural history, and mortality. Mov Disord 1998, 13(6):885-894.

3. Bower JH, Maraganore DM, McDonnell SK, Rocca WA: Incidence and distribution of parkinsonism in Olmsted County, Minnesota, 1976-1990. Neurology 1999, 52(6): |2|4-1220.

4. Polymeropoulos MH, Lavedan C, Leroy E, Ide SE, Dehejia A, Dutra A, Pike B, Root H, Rubenstein J, Boyer R, Stenroos ES, Chandrasekharappa S, Athanassiadou A, Papapetropoulos T, Johnson WG, Lazzarini AM, Duvoisin RC, Di lorio G, Golbe LI, Nussbaum RL: Mutation in the alpha-synuclein gene identified in families with Parkinson's disease. Science (New York, NY) 1997, 276(532 I):2045-2047.

5. Kitada T, Asakawa S, Hattori N, Matsumine $H$, Yamamura $Y$, Minoshima S, Yokochi M, Mizuno Y, Shimizu N: Mutations in the parkin gene cause autosomal recessive juvenile parkinsonism. Nature 1998, 392(6676):605-608.

6. Valente EM, Bentivoglio AR, Dixon PH, Ferraris A, lalongo T, Frontali $M$, Albanese A, Wood NW: Localization of a novel locus for autosomal recessive early-onset parkinsonism, PARK6, on human chromosome Ip35-p36. Am J Hum Genet 200I, 68(4):895-900.

7. van Duijn CM, Dekker MC, Bonifati V, Galjaard RJ, Houwing-Duistermaat JJ, Snijders PJ, Testers L, Breedveld GJ, Horstink M, Sandkuijl LA, van Swieten IC, Oostra BA, Heutink P: Park7, a novel locus for autosomal recessive early-onset parkinsonism, on chromosome Ip36. Am J Hum Genet 200I, 69(3):629-634.

8. Paisan-Ruiz C, Jain S, Evans EW, Gilks WP, Simon J, Brug M van der, Lopez de Munain A, Aparicio S, Gil AM, Khan N, Johnson J, Martinez JR, Nicholl D, Carrera IM, Pena AS, de Silva R, Lees A, Marti-Masso JF, Perez-Tur J, Wood NW, Singleton AB: Cloning of the gene containing mutations that cause PARK8-linked Parkinson's disease. Neuron 2004, 44(4):595-600.

9. Sun M, Latourelle JC, Wooten GF, Lew MF, Klein C, Shill HA, Golbe LI, Mark MH, Racette BA, Perlmutter JS, Parsian A, Guttman M, Nicholson G, Xu G, Wilk JB, Saint-Hilaire MH, DeStefano AL, Prakash R, Williamson S, Suchowersky O, Labelle N, Growdon JH, Singer C, Watts RL, Goldwurm S, Pezzoli G, Baker KB, Pramstaller PP, Burn DJ, Chinnery PF, Sherman S, Vieregge P, Litvan I, Gillis T, MacDonald ME, Myers RH, Gusella JF: Influence of heterozygosity for parkin mutation on onset age in familial Parkinson disease: the GenePD study. Arch Neurol 2006, 63(6):826-832.
10. Foroud T, Uniacke SK, Liu L, Pankratz N, Rudolph A, Halter C, Shults C, Marder K, Conneally PM, Nichols WC: Heterozygosity for a mutation in the parkin gene leads to later onset Parkinson disease. Neurology 2003, 60(5):796-80I.

II. Nichols WC, Pankratz N, Hernandez D, Paisan-Ruiz C, Jain S, Halter CA, Michaels VE, Reed T, Rudolph A, Shults CW, Singleton A, Foroud T: Genetic screening for a single common LRRK2 mutation in familial Parkinson's disease. Lancet 2005, 365(9457):4I 0-4I2.

12. Latourelle JC, Sun M, Lew MF, Suchowersky O, Klein C, Golbe LI, Mark MH, Growdon JH, Wooten GF, Watts RL, Guttman M, Racette BA, Perlmutter JS, Ahmed A, Shill HA, Singer C, Goldwurm S, Pezzoli G, Zini M, Saint-Hilaire MH, Hendricks AE, Williamson S, Nagle MW, Wilk JB, Massood T, Huskey KW, Laramie JM, Destefano AL, Baker KB, Itin I, Litvan I, Nicholson G, Corbett A, Nance M, Drasby E, Isaacson S, Burn DJ, Chinnery PF, Pramstaller PP, AI-Hinti J, Moller AT, Ostergaard K, Sherman SJ, Roxburgh R, Snow B, Slevin JT, Cambi F, Gusella JF, Myers RH: The Gly2019Ser mutation in LRRK2 is not fully penetrant in familial Parkinson's Disease: the GenePD study. BMC Med 2008, 6(I):32.

13. Goldwurm S, Zini M, Mariani L, Tesei S, Miceli R, Sironi F, Clementi M, Bonifati V, Pezzoli G: Evaluation of LRRK2 G2019S penetrance: relevance for genetic counseling in Parkinson disease. Neurology 2007, 68(14): ||4|-||43.

14. Maher NE, Golbe LI, Lazzarini AM, Mark MH, Currie LJ, Wooten GF, Saint-Hilaire M, Wilk JB, Volcjak J, Maher JE, Feldman RG, Guttman M, Lew M, Waters CH, Schuman S, Suchowersky O, Lafontaine AL, Labelle N, Vieregge P, Pramstaller PP, Klein C, Hubble J, Reider C, Growdon J, Watts R, Montgomery E, Baker K, Singer C, Stacy M, Myers RH: Epidemiologic study of 203 sibling pairs with Parkinson's disease: the GenePD study. Neurology 2002, 58(I):79-84.

15. Maher NE, Currie LJ, Lazzarini AM, Wilk JB, Taylor CA, Saint-Hilaire MH, Feldman RG, Golbe LI, Wooten GF, Myers RH: Segregation analysis of Parkinson disease revealing evidence for a major causative gene. American journal of medical genetics 2002, 109(3): 191-197.

16. McDonnell SK, Schaid DJ, Elbaz A, Strain KJ, Bower JH, Ahlskog JE, Maraganore DM, Rocca WA: Complex segregation analysis of Parkinson's disease: The Mayo Clinic Family Study. Annals of neurology 2006, 59(5):788-795.

17. Zareparsi S, Taylor TD, Harris EL, Payami H: Segregation analysis of Parkinson disease. American journal of medical genetics 1998, 80(4):410-4I7

18. Fung HC, Scholz S, Matarin M, Simon-Sanchez J, Hernandez D, Britton A, Gibbs JR, Langefeld C, Stiegert ML, Schymick J, Okun MS, Mandel RJ, Fernandez HH, Foote KD, Rodriguez RL, Peckham E, De Vrieze FW, Gwinn-Hardy K, Hardy JA, Singleton A: Genome-wide genotyping in Parkinson's disease and neurologically normal controls: first stage analysis and public release of data. Lancet neurology 2006, 5(II):91I-916.

19. Maraganore DM, de Andrade M, Lesnick TG, Strain KJ, Farrer MJ, Rocca WA, Pant PV, Frazer KA, Cox DR, Ballinger DG: High-resolution whole-genome association study of Parkinson disease. American journal of human genetics 2005, 77(5):685-693.

20. Pankratz N, Wilk JB, Latourelle JC, DeStefano AL, Halter C, Pugh EW, Doheny KF, Gusella JF, Nichols WC, Foroud T, Myers RH: Genomewide association study for susceptibility genes contributing to familial Parkinson disease. Human genetics 2009, I 24(6):593-605.

21. Gibb WR, Lees AJ: The relevance of the Lewy body to the pathogenesis of idiopathic Parkinson's disease. Journal of neurology, neurosurgery, and psychiatry 1988, 5 I (6):745-752.

22. Pankratz N, Nichols WC, Uniacke SK, Halter C, Rudolph A, Shults C, Conneally PM, Foroud T: Genome screen to identify susceptibility genes for Parkinson disease in a sample without parkin mutations. American journal of human genetics 2002, 7 I(I): I 24-135.

23. Pankratz N, Pauciulo MW, Elsaesser VE, Marek DK, Halter CA Rudolph A, Shults CW, Foroud T, Nichols WC: Mutations in LRRK2 other than G2019S are rare in a north Americanbased sample of familial Parkinson's disease. Mov Disord 2006, 2 ( ( I 2):2257-2260.

24. Nichols WC, Elsaesser VE, Pankratz N, Pauciulo MW, Marek DK, Halter CA, Rudolph A, Shults CW, Foroud T: LRRK2 mutation analysis in Parkinson disease families with evidence of linkage to PARK8. Neurology 2007, 69(18): 1737-1744. 
25. Nichols WC, Uniacke SK, Pankratz N, Reed T, Simon DK, Halter C, Rudolph A, Shults CW, Conneally PM, Foroud T: Evaluation of the role of Nurrl in a large sample of familial Parkinson's disease. Mov Disord 2004, 19(6):649-655.

26. Karamohamed S, Golbe LI, Mark MH, Lazzarini AM, Suchowersky O, Labelle N, Guttman M, Currie LJ, Wooten GF, Stacy M, Saint-Hilaire M, Feldman RG, Liu J, Shoemaker CM, Wilk JB, DeStefano AL, Latourelle JC, Xu G, Watts R, Growdon J, Lew M, Waters C, Vieregge P, Pramstaller PP, Klein C, Racette BA, Perlmutter JS, Parsian A, Singer C, Montgomery E, Baker K, Gusella JF, Herbert A, Myers $\mathrm{RH}$ : Absence of previously reported variants in the SCNA (G88C and G209A), NR4A2 (T29ID and T245G) and the DJI (T497C) genes in familial Parkinson's disease from the GenePD study. Mov Disord 2005, 20(9): I I88-1।91.

27. Pankratz N, Nichols WC, Elsaesser VE, Pauciulo MW, Marek DK, Halter CA, Wojcieszek J, Rudolph A, Pfeiffer RF, Foroud T: Alphasynuclein and familial Parkinson's disease. Mov Disord 2009, 24(8): ||25-||3|.

28. Reider CR, Halter CA, Castelluccio PF, Oakes D, Nichols WC, Foroud T: Reliability of reported age at onset for Parkinson's disease. Mov Disord 2003, I 8(3):275-279.

29. Gunderson KL, Steemers FJ, Ren H, Ng P, Zhou L, Tsan C, Chang W, Bullis D, Musmacker J, King C, Lebruska LL, Barker D, Oliphant A, Kuhn KM, Shen R: Whole-genome genotyping. Methods in enzymology 2006, 41 0:359-376.

30. Sanna S, Jackson AU, Nagaraja R, Willer CJ, Chen WM, Bonnycastle LL, Shen H, Timpson N, Lettre G, Usala G, Chines PS, Stringham HM, Scott LJ, Dei M, Lai S, Albai G, Crisponi L, Naitza S, Doheny KF, Pugh EW, Ben-Shlomo Y, Ebrahim S, Lawlor DA, Bergman RN, Watanabe RM, Uda M, Tuomilehto J, Coresh J, Hirschhorn JN, Shuldiner AR, Schlessinger D, Collins FS, Davey Smith G, Boerwinkle E, Cao A, Boehnke M, Abecasis GR, Mohlke KL: Common variants in the GDF5-UQCC region are associated with variation in human height. Nat Genet 2008, 40(2): 198-203.

31. Willer CJ, Sanna S, Jackson AU, Scuteri A, Bonnycastle LL, Clarke R, Heath SC, Timpson NJ, Najjar SS, Stringham HM, Strait J, Duren WL, Maschio A, Busonero F, Mulas A, Albai G, Swift AJ, Morken MA, Narisu N, Bennett D, Parish S, Shen H, Galan P, Meneton P, Hercberg S, Zelenika D, Chen WM, Li Y, Scott LJ, Scheet PA, Sundvall J, Watanabe RM, Nagaraja R, Ebrahim S, Lawlor DA, Ben-Shlomo Y, Davey-Smith G, Shuldiner AR, Collins R, Bergman RN, Uda M, Tuomilehto J, Cao A, Collins FS, Lakatta E, Lathrop GM, Boehnke M, Schlessinger D, Mohlke KL, Abecasis GR: Newly identified loci that influence lipid concentrations and risk of coronary artery disease. Nat Genet 2008, 40(2):161-169.

32. Li Y, Abecasis G: Mach I.0: Rapid Haplotype Reconstruction and Missing Genotype Inference. American journal of human genetics 2006, S79:2290.

33. The International HapMap Project. Nature 2003, 426(6968):789-796.

34. Genome-wide association study of 14,000 cases of seven common diseases and 3,000 shared controls. Nature 2007, 447(7 | 45):66I-678.

35. Marchini J, Howie B, Myers S, McVean G, Donnelly P: A new multipoint method for genome-wide association studies by imputation of genotypes. Nat Genet 2007, 39(7):906-9/3.

36. Lettre G, Lange C, Hirschhorn JN: Genetic model testing and statistical power in population-based association studies of quantitative traits. Genetic epidemiology 2007, 3 I (4):358-362.

37. de Bakker PI, Ferreira MA, Jia X, Neale BM, Raychaudhuri S, Voight $\mathrm{BF}$ : Practical aspects of imputation-driven meta-analysis of genome-wide association studies. Hum Mol Genet 2008, I7(R2):RI22-I 28.

38. Biasiotto G, Goldwurm S, Finazzi D, Tunesi S, Zecchinelli A, Sironi F, Pezzoli G, Arosio P: HFE gene mutations in a population of Italian Parkinson's disease patients. Parkinsonism Relat Disord 2008, I 4(5):426-430.

39. Purcell S, Neale B, Todd-Brown K, Thomas L, Ferreira MA, Bender D, Maller J, Sklar P, de Bakker PI, Daly MJ, Sham PC: PLINK: a tool set for whole-genome association and population-based linkage analyses. American journal of human genetics 2007, 8 I (3):559-575.

40. Risch N, Merikangas $\mathrm{K}$ : The future of genetic studies of complex human diseases. Science 1996, 273(528I):1516-1517.

4I. Pe'er I, Yelensky R, Altshuler D, Daly MJ: Estimation of the multiple testing burden for genomewide association studies of nearly all common variants. Genetic epidemiology 2008, 32(4):38I-385.

42. Dudbridge F, Gusnanto A: Estimation of significance thresholds for genomewide association scans. Genetic epidemiology 2008, 32(3):227-234.

43. Lee ST, Nicholls RD, Bundey S, Laxova R, Musarella M, Spritz RA: Mutations of the $P$ gene in oculocutaneous albinism, ocular albinism, and Prader-Willi syndrome plus albinism. N Engl J Med 1994, 330(8):529-534.

44. Rebbeck TR, Kanetsky PA, Walker AH, Holmes R, Halpern AC, Schuchter LM, Elder DE, Guerry D: $\mathbf{P}$ gene as an inherited biomarker of human eye color. Cancer Epidemiol Biomarkers Prev 2002, I I (8):782-784.

45. Sulem P, Gudbjartsson DF, Stacey SN, Helgason A, Rafnar T, Magnusson KP, Manolescu A, Karason A, Palsson A, Thorleifsson G, Jakobsdottir $M$, Steinberg $S$, Palsson S, Jonasson F, Sigurgeirsson B, Thorisdottir K, Ragnarsson R, Benediktsdottir KR, Aben KK, Kiemeney LA, Olafsson JH, Gulcher J, Kong A, Thorsteinsdottir U, Stefansson K: Genetic determinants of hair, eye and skin pigmentation in Europeans. Nat Genet 2007, 39(I 2): | 443- I 452.

46. Zhu G, Evans DM, Duffy DL, Montgomery GW, Medland SE, Gillespie NA, Ewen KR, Jewell M, Liew YW, Hayward NK, Sturm RA, Trent JM, Martin NG: A genome scan for eye color in $\mathbf{5 0 2}$ twin families: most variation is due to a QTL on chromosome I5q. Twin Res 2004, 7(2): 197-210.

47. Duffy DL, Montgomery GW, Chen W, Zhao ZZ, Le L, James MR, Hayward NK, Martin NG, Sturm RA: A three-single-nucleotide polymorphism haplotype in intron I of OCA2 explains most human eye-color variation. American journal of human genetics 2007, 80(2):24I-252.

48. Frudakis T, Terravainen T, Thomas M: Multilocus OCA2 genotypes specify human iris colors. Human genetics 2007, 122(34):3II-326.

49. Jannot AS, Meziani R, Bertrand G, Gerard B, Descamps V, Archimbaud A, Picard C, Ollivaud L, Basset-Seguin N, Kerob D, Lanternier G, Lebbe C, Saiag P, Crickx B, Clerget-Darpoux F, Grandchamp B, Soufir N, Melan C: Allele variations in the OCA2 gene (pinkeyed-dilution locus) are associated with genetic susceptibility to melanoma. Eur J Hum Genet 2005, 13(8):913-920.

50. Driver JA, Logroscino G, Buring JE, Gaziano JM, Kurth T: A prospective cohort study of cancer incidence following the diagnosis of Parkinson's disease. Cancer Epidemiol Biomarkers Prev 2007, 16(6): 1260-1265.

5I. Olsen JH, Friis S, Frederiksen K: Malignant melanoma and other types of cancer preceding Parkinson disease. Epidemiology 2006, I 7(5):582-587.

52. Olsen JH, Friis S, Frederiksen K, McLaughlin JK, Mellemkjaer L, Moller $\mathrm{H}$ : Atypical cancer pattern in patients with Parkinson's disease. $\mathrm{Br} J$ Cancer 2005, 92(I):20I-205.

53. Herrero Hernandez E: Pigmentation genes link Parkinson's disease to melanoma, opening a window on both etiologies. Med Hypotheses 2009, 72(3):280-284.

54. Sturm RA, Teasdale RD, Box NF: Human pigmentation genes: identification, structure and consequences of polymorphic variation. Gene 200I, 277(I-2):49-62.

55. Fedorow H, Tribl F, Halliday G, Gerlach M, Riederer P, Double KL: Neuromelanin in human dopamine neurons: comparison with peripheral melanins and relevance to Parkinson's disease. Prog Neurobiol 2005, 75(2): 109-124.

56. Smith AP, Hoek K, Becker D: Whole-genome expression profiling of the melanoma progression pathway reveals marked molecular differences between nevi/melanoma in situ and advanced-stage melanomas. Cancer Biol Ther 2005, 4(9): $1018-1029$.

57. Marciniak SJ, Ron D: Endoplasmic reticulum stress signaling in disease. Physiol Rev 2006, 86(4): I I33- I I49.

58. Lindholm D, Wootz H, Korhonen L: ER stress and neurodegenerative diseases. Cell Death Differ 2006, I3(3):385-392.

59. Rao RV, Bredesen DE: Misfolded proteins, endoplasmic reticulum stress and neurodegeneration. Curr Opin Cell Biol 2004, 16(6):653-662.

60. Ryu EJ, Harding HP, Angelastro JM, Vitolo OV, Ron D, Greene LA: Endoplasmic reticulum stress and the unfolded protein response in cellular models of Parkinson's disease. J Neurosci 2002, 22(24): 10690-10698. 
6I. Cooper AA, Gitler AD, Cashikar A, Haynes CM, Hill KJ, Bhullar B, Liu K, Xu K, Strathearn KE, Liu F, Cao S, Caldwell KA, Caldwell GA, Marsischky G, Kolodner RD, Labaer J, Rochet JC, Bonini NM, Lindquist S: Alpha-synuclein blocks ER-Golgi traffic and Rabl rescues neuron loss in Parkinson's models. Science 2006, 3 I 3(5785):324-328.

62. Hoozemans JJ, van Haastert ES, Eikelenboom P, de Vos RA, Rozemuller JM, Scheper W: Activation of the unfolded protein response in Parkinson's disease. Biochem Biophys Res Commun 2007, 354(3):707-7II.

63. Gasser T: Genetics of Parkinson's disease. Annals of neurology 1998, 44(3 Suppl I):S53-57.

64. DeStefano AL, Lew MF, Golbe LI, Mark MH, Lazzarini AM, Guttman M, Montgomery E, Waters CH, Singer C, Watts RL, Currie L], Wooten GF, Maher NE, Wilk JB, Sullivan KM, Slater KM, Saint-Hilaire $\mathrm{MH}$, Feldman RG, Suchowersky O, Lafontaine AL, Labelle N, Growdon JH, Vieregge P, Pramstaller PP, Klein C, Hubble JP, Reider CR, Stacy M, MacDonald ME, Gusella JF, Myers RH: PARK3 influences age at onset in Parkinson disease: a genome scan in the GenePD study. American journal of human genetics 2002, 70(5): 1089-1095.

65. Pankratz N, Uniacke SK, Halter CA, Rudolph A, Shults CW, Conneally PM, Foroud T, Nichols WC: Genes influencing Parkinson disease onset: replication of PARK 3 and identification of novel loci. Neurology 2004, 62(9): 1616-1618.

66. Zhang $\mathrm{Y}$, James M, Middleton FA, Davis RL: Transcriptional analysis of multiple brain regions in Parkinson's disease supports the involvement of specific protein processing, energy metabolism, and signaling pathways, and suggests novel disease mechanisms. Am J Med Genet B Neuropsychiatr Genet 2005, I37B(I):5-16.

67. Henderson DM, Conner SD: A novel AAKI splice variant functions at multiple steps of the endocytic pathway. Mol Biol Cell 2007, I 8(7):2698-2706.

68. Kametaka S, Moriyama K, Burgos PV, Eisenberg E, Greene LE, Mattera $R$, Bonifacino JS: Canonical interaction of cyclin $\mathbf{G}$ associated kinase with adaptor protein I regulates lysosomal enzyme sorting. Mol Biol Cell 2007, I 8(8):299I-300I.

69. Sevlever D, Jiang P, Yen SH: Cathepsin D is the main lysosomal enzyme involved in the degradation of alpha-synuclein and generation of its carboxy-terminally truncated species. Biochemistry 2008, 47(36):9678-9687.

70. Li YJ, Scott WK, Hedges DJ, Zhang F, Gaskell PC, Nance MA, Watts RL, Hubble JP, Koller WC, Pahwa R, Stern MB, Hiner BC, Jankovic J Allen FA Jr, Goetz CG, Mastaglia F, Stajich JM, Gibson RA, Middleton LT, Saunders AM, Scott BL, Small GW, Nicodemus KK, Reed AD, Schmechel DE, Welsh-Bohmer KA, Conneally PM, Roses AD, Gilbert JR, Vance JM, Haines JL, Pericak-Vance MA: Age at onset in two common neurodegenerative diseases is genetically controlled. American journal of human genetics 2002, 70(4):985-993.

7I. Bouchard L, Bouchard C, Chagnon YC, Perusse L: Evidence of linkage and association with body fatness and abdominal fat on chromosome I 5q26. Obesity (Silver Spring) 2007, I 5(8):206 I-2070.

72. Verma R, Holmans P, Knowles JA, Grover D, Evgrafov OV, Crowe RR, Scheftner WA, Weissman MM, DePaulo JR Jr, Potash JB, Levinson DF: Linkage disequilibrium mapping of a chromosome I 5q25-26 major depression linkage region and sequencing of NTRK3. Biol Psychiatry 2008, 63(I 2): I I85-II89.

73. Djousse L, Knowlton B, Hayden MR, Almqvist EW, Brinkman RR Ross CA, Margolis RL, Rosenblatt A, Durr A, Dode C, Morrison PJ, Novelletto A, Frontali M, Trent RJ, McCusker E, Gomez-Tortosa E, Mayo Cabrero D, Jones R, Zanko A, Nance M, Abramson RK, Suchowersky O, Paulsen JS, Harrison MB, Yang Q, Cupples LA, Mysore J, Gusella JF, MacDonald ME, Myers RH: Evidence for a modifier of onset age in Huntington disease linked to the HD gene in 4p I 6. Neurogenetics 2004, 5(2): |09-I| 4.

74. Wexler NS, Lorimer J, Porter J, Gomez F, Moskowitz C, Shackell E Marder K, Penchaszadeh G, Roberts SA, Gayan J, Brocklebank D, Cherny SS, Cardon LR, Gray J, Dlouhy SR, Wiktorski S, Hodes ME, Conneally PM, Penney JB, Gusella J, Cha JH, Irizarry M, Rosas D, Hersch S, Hollingsworth Z, MacDonald M, Young AB, Andresen JM, Housman DE, De Young MM, Bonilla E, Stillings T, Negrette A Snodgrass SR, Martinez-Jaurrieta MD, Ramos-Arroyo MA, Bickham J Ramos JS, Marshall F, Shoulson I, Rey GJ, Feigin A, Arnheim N, Acevedo-Cruz A, Acosta L, Alvir J, Fischbeck K, Thompson LM, Young A, Dure L, O'Brien CJ, Paulsen J, Brickman A, Krch D, Peery
S, Hogarth P, Higgins DS Jr, Landwehrmeyer B: Venezuelan kindreds reveal that genetic and environmental factors modulate Huntington's disease age of onset. Proceedings of the National Academy of Sciences of the United States of America 2004, I0I(10):3498-3503.

75. Andresen JM, Gayan J, Cherny SS, Brocklebank D, Alkorta-Aranburu G, Addis EA, Cardon LR, Housman DE, Wexler NS: Replication of twelve association studies for Huntington's disease residual age of onset in large Venezuelan kindreds. J Med Genet 2007, 44(I):44-50.

\section{Pre-publication history}

The pre-publication history for this paper can be accessed here:

http://www.biomedcentral.com/1471-2350/10/98/pre pub
Publish with BioMed Central and every scientist can read your work free of charge

"BioMed Central will be the most significant development for disseminating the results of biomedical research in our lifetime. "

Sir Paul Nurse, Cancer Research UK

Your research papers will be:

- available free of charge to the entire biomedical community

- peer reviewed and published immediately upon acceptance

- cited in PubMed and archived on PubMed Central

- yours - you keep the copyright
BioMedcentral 